Tohoku J. exp. Med., 1979, 129, 103-104

Short Report

\title{
Significance of Erwinia in the Vagina as Causative Agents of Urinary Tract Infections
}

\author{
Takusei Umenat, Yoshiniko Sattoh, Shoichi Takano,* \\ Etsuko Shoj,,* Kyoko Tanaka* and Nakao Ishida* \\ Central Clinical Laboratory and *Department of Bacteriology, \\ Tohoku University School of Medicine, Sendai 980
}

Umenai, T., SaItoh, Y., Takano, S., Shoji, E., Tanaka, K. and Ishida, N. Significance of Erwinia in the Vagina as Causative Agents of Urinary Tract Infections. Tohoku J. exp. Med., 1979, 129 (1), 103-104_. The isolation of Erwiniae from the vagina became positive just before the occurrence of erwiniuria. It is proposed that the appearance of Erwiniae in the vagina is an important indicator in the prediction of urinary tract infection by Erwiniae. Erwinia; bacterial infection

The isolation of Erwiniae species, well known plant pathogens, from human sources has been reported by several authors (Slotnick and Tulman 1967; Gilardi et al. 1970; Meyers et al. 1972). Erwiniae, isolated in pure culture from brain abscesses and blood, clearly suggest their definite pathogenicity in man. However, it is still not clear whether Erwiniae are a permanent or a transient part of the normal human flora or how they cause infection. The possible roles of certain bacteria, occasionally colonizing in the vagina, as the causative agents of urinary tract infections in women, have already been reported (Stamey 1972). This study was designed to examine the occurrence of Erwiniae in the vaginas, feces and throats of three female patients in relation to the manifestation of erwiniuria. Two of the patients in whom erwiniuria was observed had been hospitalized with uterus cancer and the third with acute myeloic leukemia. The appearance of erwiniuria was observed while patients were undergoing antibiotics treatment for the urinary tract infections caused by other bacterial species such as Klebsiella or E. coli. The isolation of Erwiniae from the vaginas became positive in all three cases just before the appearance of erwiniuria and erwiniuria lasted from 1 to 3 weeks. However, the isolation of Erwiniae from the vaginas became negative while erwiniuria still continued, suggesting that Erwiniae isolated from the vaginas were not contaminants from the urine. All the cultures made with the throats and feces of the patients were negative for Erwiniae. These results are in accord with those of Stamey (1972) who reported the intimate relationship between the colonization of certain bacteria in the vaginas and the occurrence of urinary tract infection caused by the bacteria. Thus, it seems that Erwiniae colonizing in the vagina could be the causative agents of urinary tract infections, although it is still unclear how they invade and become localized within the vagina. Isolated Erwiniae, which were short gram negative fermentative bacilli that formed yellow pigmented colonies, were referred to the Department of Bacteriology, Tohoku University School of Medicine for confirmation. All Erwiniae specimens isolated were identified as Erwinia herbicola and were found to be resistant to various synthetic penicillins, cephalosporines and kanamycin but were sensitive to kanamycin derivatives and colistin.

The circumstances involved here (i.e. aged patients with uterus cancer or leukemia

Received for publication, February 20, 1979. 
TABLE 1. Summary of female patients with erwiniuria

\begin{tabular}{|c|c|c|c|c|c|c|c|c|}
\hline \multirow{2}{*}{$\begin{array}{l}\text { Patient } \\
-1 \text { (H.S.) }\end{array}$} & \multirow{2}{*}{$\begin{array}{r}\text { Age } \\
66\end{array}$} & \multirow{2}{*}{$\frac{\text { Diagnosis }}{\text { Uterus cancer }}$} & \multirow{2}{*}{$\begin{array}{c}\begin{array}{c}\text { Source of } \\
\text { culture }\end{array} \\
\text { Urine }\end{array}$} & \multicolumn{4}{|c|}{ Examination of Erwinia* } & \multirow{2}{*}{$\begin{array}{c}\begin{array}{c}\text { Clinical } \\
\text { course }\end{array} \\
\text { Died }\end{array}$} \\
\hline & & & & $\begin{array}{r}\text { Klebsiella } \\
2 \times 10^{7} \dagger\end{array}$ & $\begin{array}{l}\text { Erwinia } \\
3.3 \times 10^{7}\end{array}$ & $\begin{array}{r}\text { Erwinia } \\
1 \times 10^{8}\end{array}$ & $\begin{array}{r}\text { Erwinia } \\
1 \times 10^{8}\end{array}$ & \\
\hline & & & Vagina & $+\ddagger$ & + & + & - & \\
\hline & & & Feces & $-\ddagger$ & - & - & - & \\
\hline & & & Throat & - & - & & $\overline{-}$ & \\
\hline \multirow[t]{4}{*}{2 (K.K.) } & 69 & Uterus cancer & Urine & $\begin{array}{r}\text { Klebsiella } \\
2.8 \times 10^{7}\end{array}$ & $\begin{array}{l}\text { E. coli } \\
1 \times 10^{4}\end{array}$ & $\begin{array}{l}\text { Erwinia } \\
2.1 \times 10^{7}\end{array}$ & $\begin{array}{l}\text { Erwinia } \\
7.3 \times 10^{4}\end{array}$ & Recovered \\
\hline & & & Vagina & - & + & + & - & \\
\hline & & & Feces & - & - & - & - & \\
\hline & & & Throat & - & - & - & - & \\
\hline \multirow[t]{4}{*}{3 (K.O.) } & 62 & $\begin{array}{l}\text { Acute myeloic } \\
\text { leukemia }\end{array}$ & Urine & ND§ & $\begin{array}{l}\text { Klebsiella } \\
1 \times 10^{6}\end{array}$ & $\begin{array}{l}\text { Erwinia } \\
4 \times 10^{6}\end{array}$ & $\begin{array}{l}\text { Erwinia } \\
3 \times 10^{4}\end{array}$ & Recovered \\
\hline & & & Vagina & ND & + & + & - & \\
\hline & & & & ND & - & - & ND & \\
\hline & & & Throat & ND & - & - & ND & \\
\hline
\end{tabular}

* Specimens were examined for the presence of Erwinia at intervals of 1 to 2 weeks.

$\dagger$ Numbers of bacteria per $\mathrm{ml}$ of urine.

$\ddagger$ Positive $(+)$ or negative $(-)$ in Erwinia culture.

$\S$ Not done.

undergoing treatment with antibiotics or immunosuppressive drugs) suggest that Erwiniae infection in human is opportunistic. Also it appears that the isolation of Erwiniae from the vagina is an important indicator in the prediction of the occurrence of urinary tract infection by Erwiniae.

\section{References}

1) Gilardi, G.L., Bottone, E. \& Birnbaum, M. (1970) Unusual fermentative, gramnegative bacilli isolated from clinical specimens: 1. Characterization of Erwinia strains of the "lathyri-herbicola group" Appl. Microbiol., 20, 151-155.

2) Meyers, B.R., Bottone, E. Hirschman, S.Z. \& Schneierson, S.S. (1972) Infections caused by microorganisms of the Genus Erwinia. Ann. intern. Med., 76, 9-14.

3) Slotnick, I.J. \& Tulman, L. (1967) A human infection caused by an Erwinia species. Amer. J. Med., 43, 147-150.

4) Stamey, T.A. (1972) Urinary infections in nonpregnant women. In: Urinary Infections, edited by T.A. Stamey, the Williams \& Wilkins Company, Baltimore, pp. 80-119. 